\title{
Diel turbidity cycles in a headwater stream: evidence of nocturnal bioturbation?
}

\author{
Richard J. Cooper ${ }^{1} \cdot$ Faye N. Outram ${ }^{1} \cdot$ Kevin M. Hiscock ${ }^{1}$
}

Received: 30 August 2015 / Accepted: 28 January 2016/Published online: 17 February 2016

(C) The Author(s) 2016. This article is published with open access at Springerlink.com

\begin{abstract}
Purpose A small number of recent studies have linked daily cycles in stream turbidity to nocturnal bioturbation by aquatic fauna, principally crayfish, and demonstrated this process can significantly impact upon water quality under baseflow conditions. Adding to this limited body of research, we use highresolution water quality monitoring data to investigate evidence of diel turbidity cycles in a lowland, headwater stream with a known signal crayfish (Pacifastacus leniusculus) population and explore a range of potential causal mechanisms. Materials and methods Automatic bankside monitoring stations measured turbidity and other water quality parameters at 30-min resolution at three locations on the River Blackwater, Norfolk, UK, during 2013. Specifically, we focused on two 20-day periods of baseflow conditions during January and April 2013 which displayed turbidity trends typical of winter and spring seasons, respectively. The turbidity time-series, which were smoothed with 6.5-h Savitzky-Golay filters to highlight diel trends, were correlated against temperature, stage, dissolved oxygen and $\mathrm{pH}$ to assess the importance of abiotic influences on turbidity. Turbidity was also calibrated against suspended particulate matter (SPM) over a wide range of values via linear regression.
\end{abstract}

Responsible editor: Geraldene Wharton

Electronic supplementary material The online version of this article (doi:10.1007/s11368-016-1372-y) contains supplementary material, which is available to authorized users.

Richard J. Cooper

Richard.J.Cooper@uea.ac.uk

1 School of Environmental Sciences, University of East Anglia, Norwich Research Park, Norwich NR4 7TJ, UK
Results and discussion Pronounced diel turbidity cycles were found at two of the three sites under baseflow conditions during April. Spring night-time turbidity values consistently peaked between 21:00 and 04:00 with values increasing by $\sim 10$ nephelometric turbidity units (NTU) compared with the lowest recorded daytime values which occurred between 10:00 and 14:00. This translated into statistically significant increases in median midnight SPM concentration of up to $76 \%$ compared with midday, with night-time (18:00-05:30) SPM loads also up to $30 \%$ higher than that recorded during the daytime (06:00-17:30). Relating turbidity to other water quality parameters exhibiting diel cycles revealed there to be neither any correlation that might indicate a causal link nor any obvious mechanistic connections to explain the temporal turbidity trends. Diel turbidity cycles were less prominent at all sites during the winter.

Conclusions Considering the seasonality and timing of elevated turbidity, visual observations of crayfish activity and an absence of mechanistic connections with other water quality parameters, the results presented here are consistent with the hypothesis that nocturnal bioturbation is responsible for generating diel turbidity cycles under baseflow conditions in headwater streams. However, further research in a variety of fluvial environments is required to better assess the spatial extent, importance and causal mechanisms of this phenomenon.

Keywords Bioturbation · Crayfish · Diurnal - Sediment . Stream $\cdot$ Suspended particulate matter

\section{Introduction}

Elevated sediment concentrations represent an important and growing threat to the sustainable ecosystem functioning of many fluvial systems across the world (Beusen et al. 2005; 
Quinton et al. 2010). Excessive amounts of suspended particulate matter (SPM) increase water turbidity, reduce light penetration to submergent macrophytes, smother benthic habitats, scour invertebrate communities and reduce the lifetimes of reservoirs (Hilton et al. 2006; Bilotta and Brazier 2008). Suspended particulate matter is also a major vector for the transport of nutrients (e.g. phosphorus) through catchments which adsorb onto the surfaces of fine-grained material, thus enhancing the risk of developing eutrophic conditions (House 2003; Evans et al. 2004).

The detrimental impacts associated with elevated SPM concentrations are, however, temporally variable. These range from seasonal variations in SPM concentration driven by changing antecedent soil moisture conditions (Meybeck et al. 1999; Halliday et al. 2014) to hourly fluctuations driven by episodic high-energy, high-flow storm events which can mobilise large volumes of material through the initiation of rapid land-to-river surface sediment transfers (Navratil et al. 2012; Cooper et al. 2015). Intriguingly, recent research in North America and Europe has also found evidence of distinct diel cycles in fluvial SPM concentrations (Gillain 2005; Loperfido et al. 2010). Turbidity measurements, which can be used as a proxy for SPM concentration after calibration, were found to be elevated during the night and lower during the day, a trend attributed to in-stream bioturbation processes. Specifically, it has been demonstrated that the feeding and burrowing activities of nocturnal fish, crayfish and other aquatic organisms stir-up and entrain into suspension fine streambed and channel bank sediments, and it has been suggested that this is responsible for peaks in night-time turbidity measurements (Harvey et al. 2011, 2014; Rice et al. 2014). There is, therefore, the potential for diel turbidity cycles to occur in other riverine environments similarly inhabited by populations of sediment-mobilising aquatic fauna. However, for turbidity cycles to be directly attributed to SPM dynamics, other factors that can influence turbidity measurements have to be considered. This includes the presence of phytoplankton, fluctuations in stream $\mathrm{pH}$ causing the precipitation of dissolved constituents and the influence of water temperature on the accuracy of turbidity instruments.

In this study, we investigated evidence of diel turbidity dynamics in the River Blackwater, a lowland agricultural tributary of the River Wensum, UK. A substantial population of non-native signal crayfish (Pacifastacus leniusculus) is present within the catchment, and this species is known to have nocturnal feeding and burrowing habits (Guan 1994; Harvey et al. 2011; Fig. 1). Therefore, the main objectives of this study were as follows:

(i) To investigate evidence of diel turbidity cycles in the River Blackwater using high-resolution (30 min) turbidity data captured by automatic bankside monitoring stations, and (ii) To understand the causal mechanisms of diel turbidity cycles by investigating the temporal dynamics of other water quality parameters that could influence turbidity measurements.

\section{Materials and methods}

\subsection{Study location}

This study focused upon the $20-\mathrm{km}^{2}$ Blackwater subcatchment of the River Wensum, Norfolk, UK (Fig. 2). This lowland, calcareous river system flows through a region of intensive agriculture, with $74 \%$ of land under arable cultivation, $14 \%$ improved grassland, $11 \%$ mixed woodland and $1 \%$ rural settlements. Surface soils are predominantly clay loam to sandy clay loam (0-0.5-m depth), and these are underlain by Quaternary deposits of chalky, flint-rich boulder clays and glaciofluvial and glaciolacustrine sands and gravels $(0.5-20 \mathrm{~m})$. The bedrock is cretaceous white chalk at a depth of $20 \mathrm{~m}$ (Hiscock et al. 1996; Lewis 2011). The stream channels have been extensively deepened and straightened through regular dredging to reduce water residence times (Fig. 1c). The site experiences a temperate maritime climate, with mean annual temperatures of $10^{\circ} \mathrm{C}$, and a mean annual rainfall total of $653 \mathrm{~mm}$ year $^{-1}$ for the 1981-2010 period (Meteorological 2013).

\subsection{Data collection}

The Blackwater catchment has been intensively monitored since 2011 as part of the River Wensum Demonstration Test Catchment project (Outram et al. 2014) and is split into six nested 'mini-catchments' A to $\mathrm{F}$ for observational purposes. Each mini-catchment has an automatic bankside kiosk at its outlet monitoring a range of water quality parameters at 30min resolution, which includes turbidity, temperature, $\mathrm{pH}$, dissolved oxygen, chlorophyll, electrical conductivity, ammonium and stage. The optical turbidity data were collected by water being drawn out of the stream via peristaltic pumps and sampled by YSI multi-parameter sondes (6600 series) mounted in flow cells. Turbidity was measured in nephelometric turbidity units (NTU), and the probes have a manufacturer-derived accuracy of $\pm 2 \%$. The kiosks at sites $\mathrm{E}$ and $\mathrm{F}$ additionally measured total phosphorus, total reactive phosphorus and nitrate, whilst two weather stations in the catchment measured precipitation and temperature at 15-min intervals.

For this study, the analysis was restricted to turbidity data collected during 2013 from the three bankside kiosks (A, B and E) with the most complete turbidity records. Further details of these three sites can be found in the Electronic 


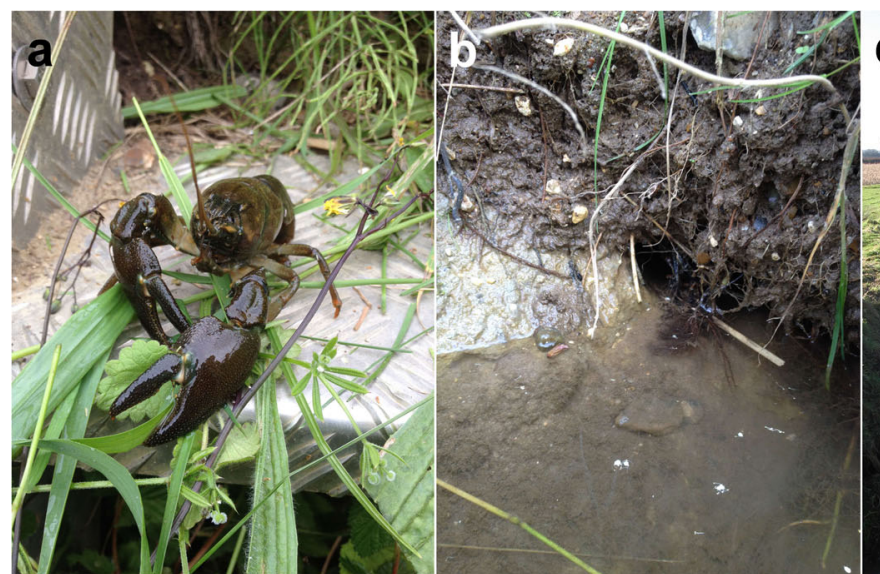

C

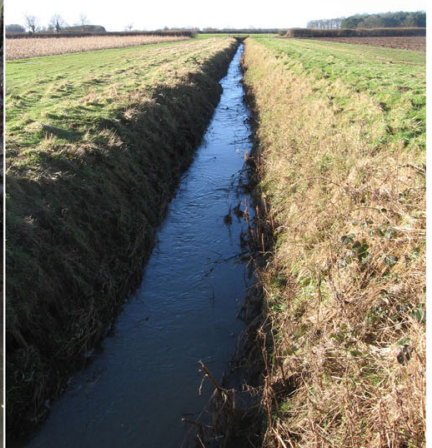

Fig. 1 a The non-native signal crayfish (Pacifastacus leniusculus) has been found throughout the Blackwater catchment, UK. This specimen was $\sim 12-\mathrm{cm}$ long. b A signal crayfish burrow carved out at the base of the stream channel bank. Diameter of burrow entrance $\sim 5 \mathrm{~cm}$. $\mathbf{c}$ The River Blackwater in mini-catchment $\mathrm{A}$, showing the straightened and deepened channel profile typical of this area. The top of the channel is $\sim 4-\mathrm{m}$ wide
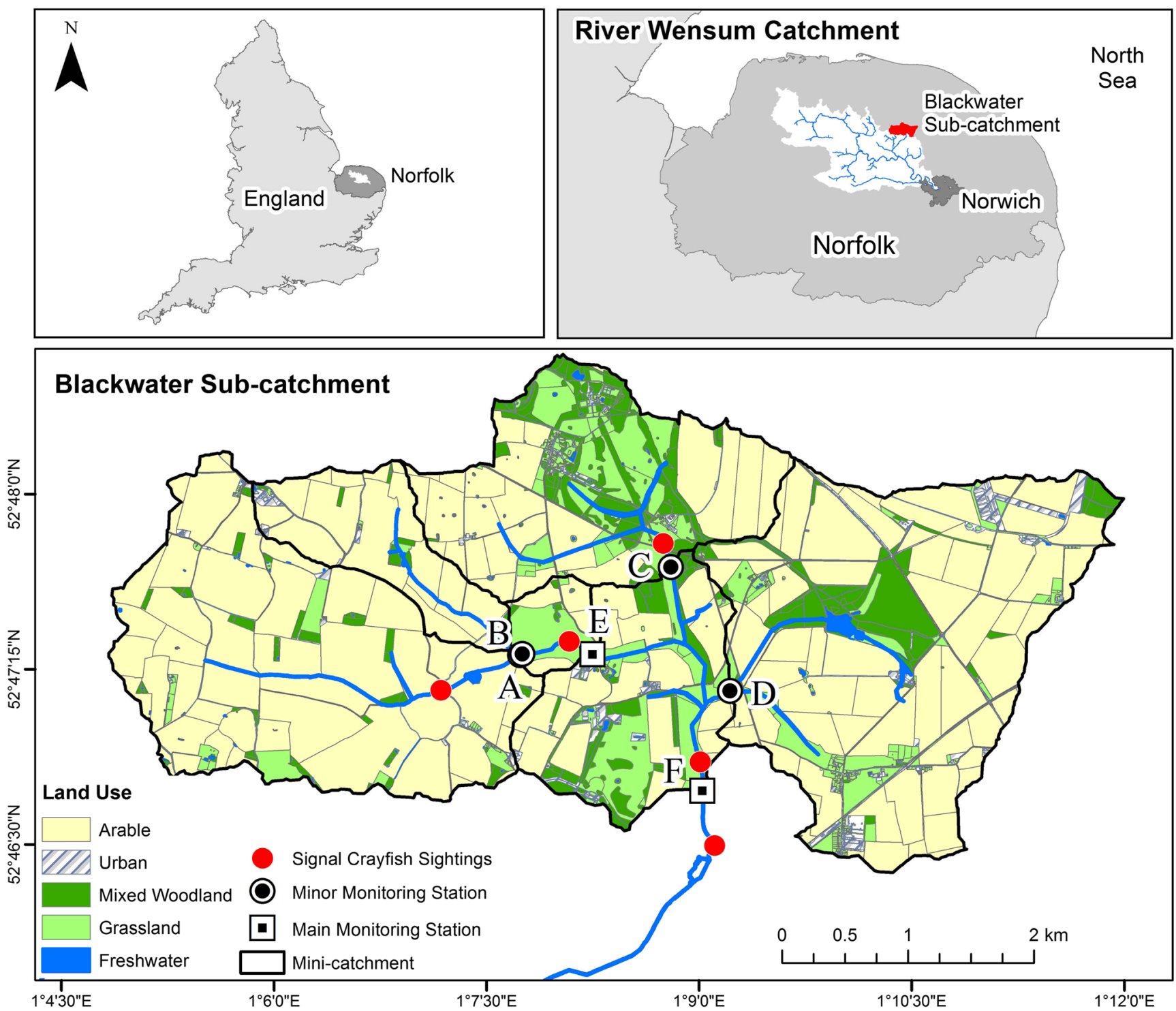

Fig. 2 The Blackwater sub-catchment, Norfolk, UK, showing land cover types, Pacifastacus leniusculus sightings and the locations of bankside monitoring stations. Pacifastacus leniusculus sightings were obtained from the National Biodiversity Network Gateway 
Supplementary Material (Online Resource 1, ESM_1). We specifically focused on two 20-day periods of baseflow conditions in January and April 2013 which displayed turbidity trends typical of winter and spring/summer seasons in the River Blackwater, respectively.

Records of $P$. leniusculus sightings $(100 \mathrm{~m}$ presence records) were provided for five locations on the River Blackwater by Norfolk Biodiversity Information Service and the Environment Agency courtesy of the National Biodiversity Network Gateway (Fig. 2). At each of the five locations, 23-25 recorded sightings of signal crayfish were made between 1986 and 2014. These were informally corroborated by further frequent sightings during weekly site visits for water quality monitoring between 2011 and 2015 .

\subsection{Data processing}

Turbidity measurements (NTU) were calibrated against SPM concentrations $\left(\mathrm{mg} \mathrm{L}^{-1}\right)$ by ordinary least squares regression using $\sim 300$ stream water grab samples collected at each of the three sites under a range of high- and low-flow conditions between May 2012 and March 2014. One litre grab samples were filtered through pre-weighed Millipore quartz fibre filter (QFF) papers with a particle retention rating of $99.3 \%$ at $0.45 \mu \mathrm{m}$ to extract SPM (Cooper et al. 2014). Filters were then oven dried at $105^{\circ} \mathrm{C}$ for $2 \mathrm{~h}$ and reweighed to determine SPM concentration.

The high-resolution $(30 \mathrm{~min})$ turbidity time-series were smoothed with 13 point $(6.5 \mathrm{~h})$, first order Savitzky-Golay filters (Savitzky and Golay 1964) to highlight underlying diel trends and to remove the spurious isolated turbidity peaks which were present throughout much of the turbidity record. This random high-frequency 'noise' in turbidity datasets has been observed in other water quality monitoring studies (e.g. Navratil et al. 2011; Sherriff et al. 2015) and is potentially linked to the temporary biofouling of the turbidity probe or debris interference around the sensor by leaves and air bubbles.

Suspended particulate matter loads were calculated from estimated SPM concentrations using stage-discharge rating curves constructed from manual flow-gauging measurements made under a wide range of flow conditions $(0.002-$ $0.543 \mathrm{~m}^{3} \mathrm{~s}^{-1}$ ) at each site. Turbidity was correlated by ordinary least squares regression against four other water quality parameters (stage, temperature, dissolved oxygen and $\mathrm{pH}$ ) to assess potential causal mechanisms.

\section{Results and discussion}

\subsection{Turbidity-suspended particulate matter (SPM) calibration}

The turbidity-SPM calibration plots (Fig. 3) demonstrate that the high-resolution turbidity measurements provide a robust proxy for SPM concentrations at sites A $\left(R^{2}=0.764\right)$, B $\left(R^{2}=0.801\right)$ and $\mathrm{E}\left(R^{2}=0.844\right)$ over a wide range of SPM concentrations (1-458 $\left.\mathrm{mg} \mathrm{L}^{-1}\right)$, turbidity values (1-758 NTU) and flow measurements $\left(0.001-0.489 \mathrm{~m}^{3} \mathrm{~s}^{-1}\right)$. The best fit linear regressions at site $\mathrm{A}$ and, in particular, site $\mathrm{B}$ have a slight offset from the zero intercept, indicating instrumental error in the optical turbidity probe. Despite this, the calibrations for sites $\mathrm{A}$ and $\mathrm{E}$ remain robust and the $R^{2}$ values are consistent with those reported in other studies (Harrington and Harrington 2013; Thompson et al. 2014).

\subsection{Diel turbidity cycles}

The 30-min resolution turbidity time-series for sites A, B and E during 2013 are presented in Fig. 4. At this timescale, the turbidity record is dominated by large-scale fluctuations $(>200$ NTU) caused by catchment-wide sediment mobilisation during heavy rainfall events, with this variability obscuring any smaller-scale diel turbidity trends. The turbidity record is also impacted by spurious 'noise' caused by random isolated turbidity peaks which can result in misinterpretation of the true stream turbidity. An example of this can be seen at site B during June and July 2013 where the mean turbidity is 7 NTU, but a small number of random isolated peaks make the turbidity appear much greater when plotted at this timescale. However, by focusing upon a period of low-flow conditions and smoothing the data with a Savitzky-Golay filter, this noise is removed, and pronounced diel turbidity cycles are revealed (Fig. 5). Shown here for a 20-day period between the 10th and 29th April 2013, sites A and E consistently recorded daily peaks in turbidity values between 21:00 and 04:00, centring around midnight. Turbidity values subsequently declined by $\sim 10$ NTU towards the lowest-recorded daytime values which occurred between 10:00 and 14:00, centring on midday.

Considering the time of sunset (20:00) and sunrise (05:45) in mid-April, the timings of these turbidity peaks and troughs are consistent with the hypothesis that nocturnal bioturbation is responsible for generating these cycles. These timings are also consistent with the observations of Harvey et al. (2014) and Rice et al. (2014), who similarly found turbidity peaked at around midnight in the River Windrush, Oxfordshire and River Nene, Northamptonshire, UK, respectively, with both studies linking these cycles to the nocturnal activities of signal crayfish.

Whilst only shown here for a 20-day period in April 2013, these diel turbidity cycles are present under baseflow conditions throughout much of spring and summer at sites $\mathrm{A}$ and $\mathrm{E}$. The cycles do, however, weaken during winter when lowerwater temperatures and higher-flow conditions have been shown to reduce crayfish activity (Bubb et al. 2002; Johnson et al. 2014). This can be seen in Fig. 6 for a 20-day period in January 2013 where the diel cycles were not evident at sites A or B. Site E retained evidence of diel cycles, but daily 


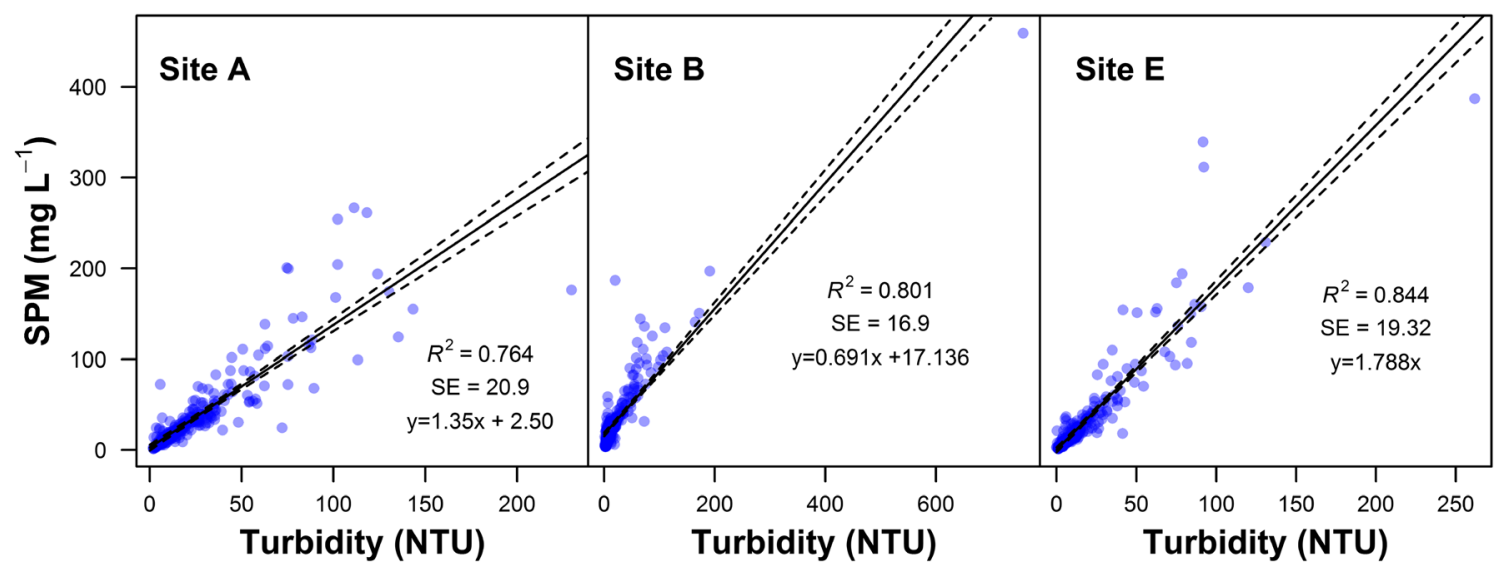

Fig. 3 Calibration plots of measured suspended particulate matter (SPM; $\mathrm{mg} \mathrm{L}^{-1}$ ) versus YSI optical turbidity measurements (NTU) for sites A $(n=299), \mathrm{B}(n=311)$ and $\mathrm{E}(n=289)$. Solid line is the linear regression, dotted lines are the $95 \%$ confidence intervals of the regression

oscillations in turbidity (3-4 NTU) were substantially lower than that observed in April ( 10 NTU), thus supporting the hypothesis of reduced crayfish activity during the winter. Diel cycles were also masked during precipitation events when larger-scale sediment mobilisation obscures these smaller diel fluctuations, an observation also made by Halliday et al. (2014). This can be seen during the precipitation events on the 12th April (Fig. 5) and 9th January (Fig. 6).

At site B, diel turbidity cycles were noticeably less pronounced during spring than observed at sites $\mathrm{A}$ and $\mathrm{E}$ (Fig. 5). Considering the close proximity of these three sites ( $<600 \mathrm{~m}$ distance), it is unlikely that wider environmental factors (e.g. temperature/rainfall variations) are responsible for the absence of diel cycles at site B. Similarly, all three sites used the same type of turbidity probe and were serviced regularly, meaning instrument effects are also unlikely to be responsible. A reduced impact from localised bioturbation could, however, explain these differences. Lower water levels ( $0.03 \mathrm{~m}$ mean stage during this period) and denser stream vegetation in mini-catchment B likely make this part of the channel less accessible to larger fish and crayfish, thus reducing the incidences of streambed and channel bank sediment disturbance from nocturnal feeding and burrowing activities. Similarly, a greater incidence of stream channel bank slumping in mini-catchment B likely reduced the availability of suitable burrowing sites compared to mini-catchments A and $\mathrm{E}$ where more frequent bank re-profiling and dredging to improve channel drainage results in steeper, cleaner bank
Fig. 4 Turbidity and stage timeseries for sites A, B and E during 2013. The grey boxes highlight the spring and winter periods investigated in Figs. 5 and 6, respectively

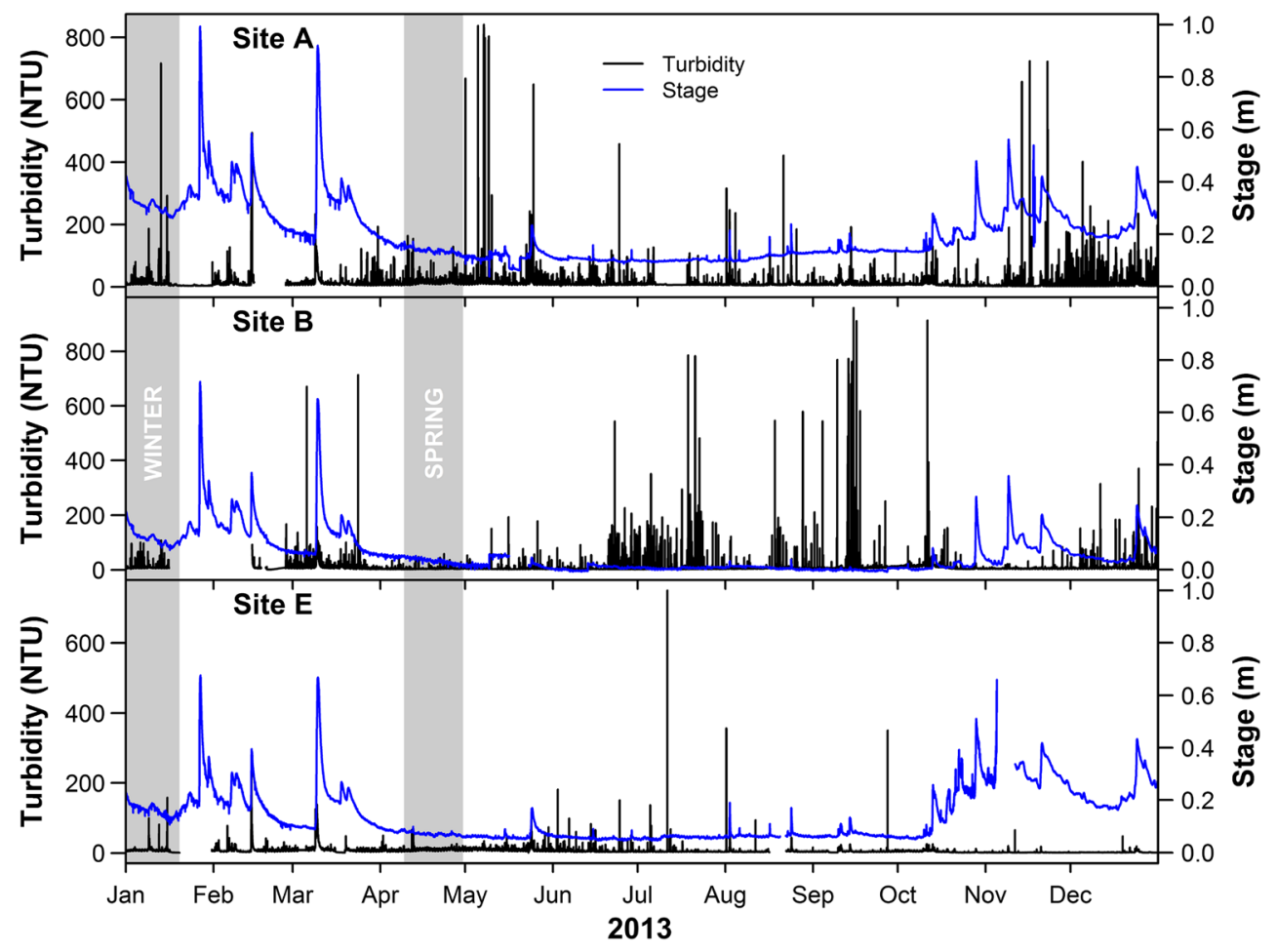


Fig. 5 Spring turbidity timeseries recorded at sites A, B and E over a 20-day period during April 2013. The smooth black line is a 13-point (6.5 h), first order Savitzky-Golay filter

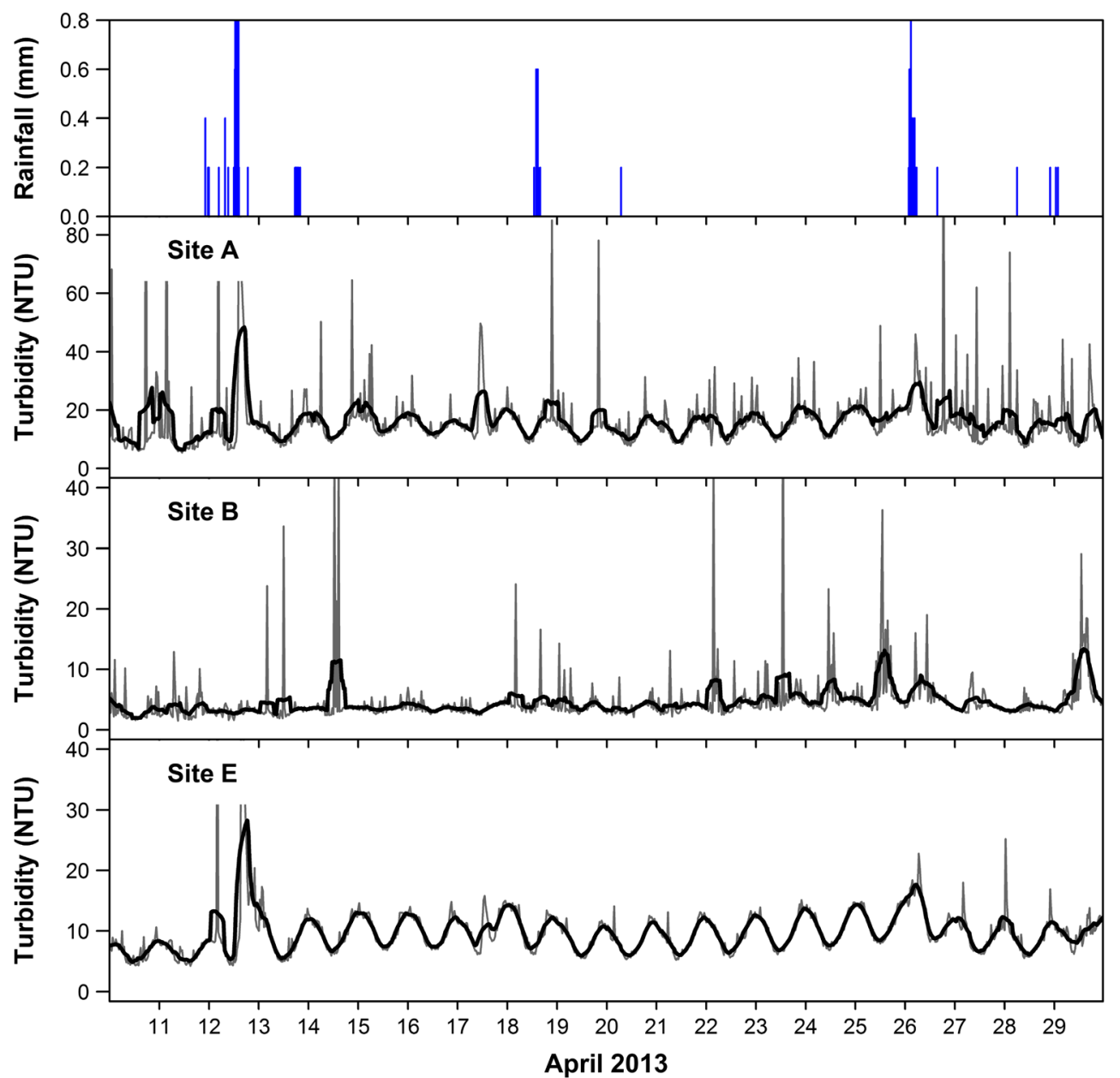

faces into which crayfish can burrow. Lastly, the bed substrate in mini-catchment B is largely gravel dominated as opposed to silt dominated in mini-catchments $\mathrm{A}$ and $\mathrm{E}$, thus limiting the availability of fine sediment for resuspension.

\subsection{Impacts on suspended particulate matter (SPM) concentration and load}

Based on the smoothed April turbidity data, these diel turbidity cycles translate into a statistically significant increase in median SPM concentration of $9.9 \mathrm{mg} \mathrm{L}^{-1}$ at site $\mathrm{A}$ and $9.3 \mathrm{mg} \mathrm{L}^{-1}$ at site $\mathrm{E}$ between midday and midnight (Table 1). In other words, median SPM concentrations increased by 55 and $76 \%$ between midday and midnight at sites $\mathrm{A}$ and $\mathrm{E}$, respectively, during this spring baseflow period. Converting this into total night-time (18:00-05:30) and daytime (06:00-17:30) SPM loads over the 20-day period reveals $75.4 \mathrm{~kg}(53.5-106.8 \mathrm{~kg}$ based on $95 \%$ confidence intervals of the stage-discharge rating curve and SPM-turbidity calibration) of SPM was exported during the night at site A, with $64.9 \mathrm{~kg}$ (46.0-91.9 kg) exported during the day. At site E, $86.7 \mathrm{~kg}(64.1-117.2 \mathrm{~kg}$ at $95 \%$ confidence interval) was exported at night, with $66.5 \mathrm{~kg}$ (49.1-90.0 kg) exported during the day. Assuming nocturnal bioturbation is the causal factor of increased SPM concentrations, these night-time SPM loads based on the smoothed turbidity data are $\sim 16 \%$ greater at site $\mathrm{A}$ and $\sim 30 \%$ greater at site E compared to what can be considered the baseline, lower bioturbation, daytime loads.

These load estimates are comparable to those obtained by Rice et al. (2014) in the headwaters of the River Nene, UK, who calculated an increase in night-time suspended sediment load of $46.9 \%$ compared to daytime load under baseflow conditions. This reduced to a $20.3 \%$ increase in night-time loads when higher-flow flood days were included due to the reduced importance of bioturbation in initiating sediment mobilisation during heavy precipitation events. In headwater streams exhibiting diel cycles in Iowa, USA, Loperfido et al. (2010) also reported that mean total phosphorus (TP) concentrations were twice as high at night $\left(0.41 \mathrm{mg} \mathrm{L}^{-1}\right)$ than during the day $\left(0.20 \mathrm{mg} \mathrm{L}^{-1}\right)$ which may be linked to elevated nighttime SPM concentrations. In our study, we found only limited evidence for this, with midnight median TP concentrations of $0.073 \mathrm{mg} \mathrm{L}^{-1}$ being marginally greater than the $0.065 \mathrm{mg} \mathrm{L}^{-1}$ recorded at midday, although this difference was not significant (Table 1). This can be explained by the relatively weak correlation between TP and SPM concentration during this 
Fig. 6 Winter turbidity timeseries recorded at sites A, B and E over a 20-day period during January 2013. The smooth black line is a 13-point $(6.5 \mathrm{~h})$, first order Savitzky-Golay filter

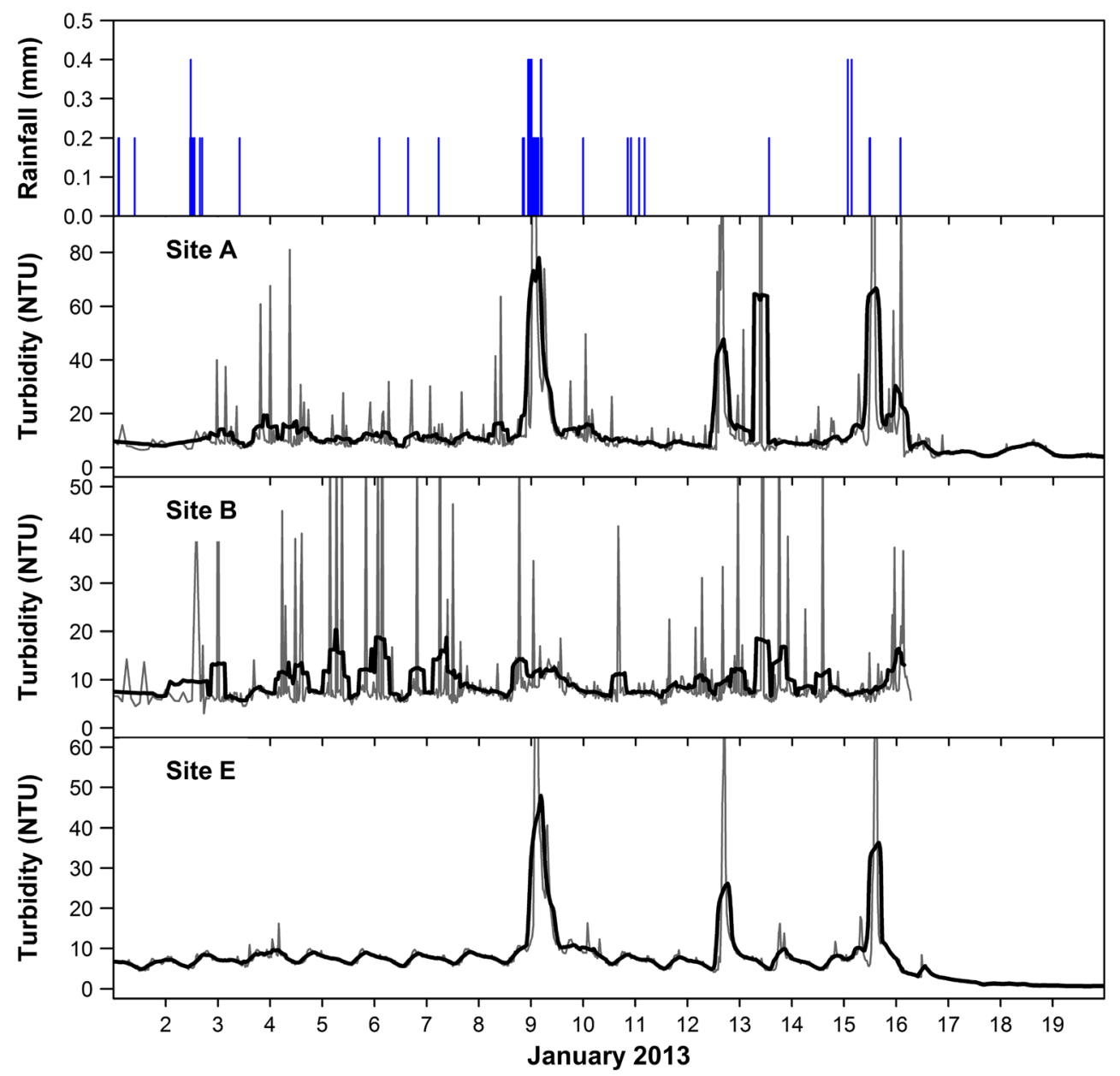

period ( $r=0.34)$ indicating that the dissolved fraction is more important than particulate material in controlling TP concentration under these low-flow conditions.

\subsection{Causal mechanisms}

With such a strong and regular diel turbidity cycle observable at sites $\mathrm{A}$ and $\mathrm{E}$ during the spring and summer months, it is important to rule out any potential instrument artefacts being responsible for inducing these trends if there is to be confidence in relating them to bioturbation. Firstly, it is necessary to recognise that turbidity is just a surrogate measure of SPM concentration and other factors, such as phytoplankton blooms, can lead to an increase in turbidity without the requirement for elevated SPM concentrations. However, the SPM-turbidity calibrations were robust over a wide range of
Table 1 Median $( \pm$ standard deviation) suspended particulate matter (SPM)

concentrations recorded throughout the day at sites $\mathrm{A}, \mathrm{B}$ and $\mathrm{E}$ during 10-29th April 2013

\begin{tabular}{|c|c|c|c|c|c|c|}
\hline \multirow[t]{2}{*}{ Location } & \multirow[t]{2}{*}{ Parameter } & \multicolumn{4}{|c|}{ Concentration $\left(\mathrm{mg} \mathrm{L}^{-1}\right)$} & \multirow{2}{*}{$\begin{array}{l}t \text { test: midday vs. } \\
\text { midnight ( } p \text { value) }\end{array}$} \\
\hline & & Midnight & $6 \mathrm{am}$ & Midday & $6 \mathrm{pm}$ & \\
\hline \multirow[t]{2}{*}{ Site A } & SPM: raw & $23.0 \pm 6.2$ & $22.9 \pm 15.0$ & $15.3 \pm 15.0$ & $23.6 \pm 6.8$ & 0.208 \\
\hline & SPM: smoothed & $27.9 \pm 4.2$ & $23.5 \pm 5.7$ & $18.0 \pm 7.5$ & $26.0 \pm 6.8$ & $<0.001$ \\
\hline \multirow[t]{2}{*}{ Site B } & SPM: raw & $19.5 \pm 0.7$ & $19.8 \pm 1.9$ & $19.5 \pm 5.5$ & $20.0 \pm 0.7$ & 0.172 \\
\hline & SPM: smoothed & $19.7 \pm 0.7$ & $19.9 \pm 1.0$ & $19.8 \pm 2.3$ & $20.1 \pm 1.0$ & 0.089 \\
\hline \multirow[t]{3}{*}{ Site E } & SPM: raw & $20.6 \pm 3.6$ & $17.4 \pm 3.8$ & $11.6 \pm 2.9$ & $16.4 \pm 6.8$ & $<0.001$ \\
\hline & SPM: smoothed & $21.4 \pm 3.6$ & $16.9 \pm 4.1$ & $12.1 \pm 2.5$ & $17.5 \pm 7.8$ & $<0.001$ \\
\hline & TP: raw & $0.073 \pm 0.021$ & $0.063 \pm 0.024$ & $0.065 \pm 0.016$ & $0.083 \pm 0.018$ & 0.486 \\
\hline
\end{tabular}

Smoothed SPM data were filtered with a 13-point $(6.5 \mathrm{~h})$, first order Savitzky-Golay filter. Total phosphorus (TP) concentrations also shown for site $\mathrm{E}$ 
values (Fig. 3), so there is confidence in relating turbidity to SPM concentrations.

Temperature is also known to affect the accuracy of turbidity measurements, with lower water temperatures leading to higher turbidity values and vice versa (Loperfido et al. 2010). Thus, an instrumental anomaly in response to diurnal temperature variations could potentially yield the same diel pattern in turbidity as observed at sites A and E. However, as can be seen in Fig. 7, temperature values at site E during April 2013 fell to a minimum just before dawn, several hours after the peak in turbidity around midnight. Additionally, weak correlation $(r=0.11)$ between temperature and turbidity implies no causal relationship exists between the two parameters. This point is emphasised during the winter when prominent diurnal temperature variations still occur, yet diel turbidity cycles weaken at this time (Fig. 6).

Along with temperature, the influence of probe exposure to sunlight can also be ruled out as a potential driver of these cycles because the turbidity probes used here were located in flow cells inside the bankside-monitoring kiosks and therefore kept in darkness. Additionally, comparison of turbidity values with an additional probe that was located instream at site $\mathrm{E}$ revealed that both probes recorded very similar diel cycles in turbidity with respect to both timing and magnitude (data not shown). Correlation of turbidity with other parameters which display diel cycles, including stage $(r=0.02)$ and dissolved oxygen $(r=0.33)$ which can both vary diurnally due to changes in temperature, transpiration and photosynthesis, revealed that changes in these parameters were also unlikely to be causal factors as they do not align with the timings of the turbidity peaks and there exists no obvious mechanistic connection (Fig. 7).

However, diel cycles in stream water $\mathrm{pH}$, which peak at around midday and decline to a minimum around midnight, do correspond more strongly with the turbidity trends. This daily $\mathrm{pH}$ variability relates to $\mathrm{CO}_{2}$ consumption during
Fig. 7 Diurnal variability in water quality parameters measured at site E during April 2013

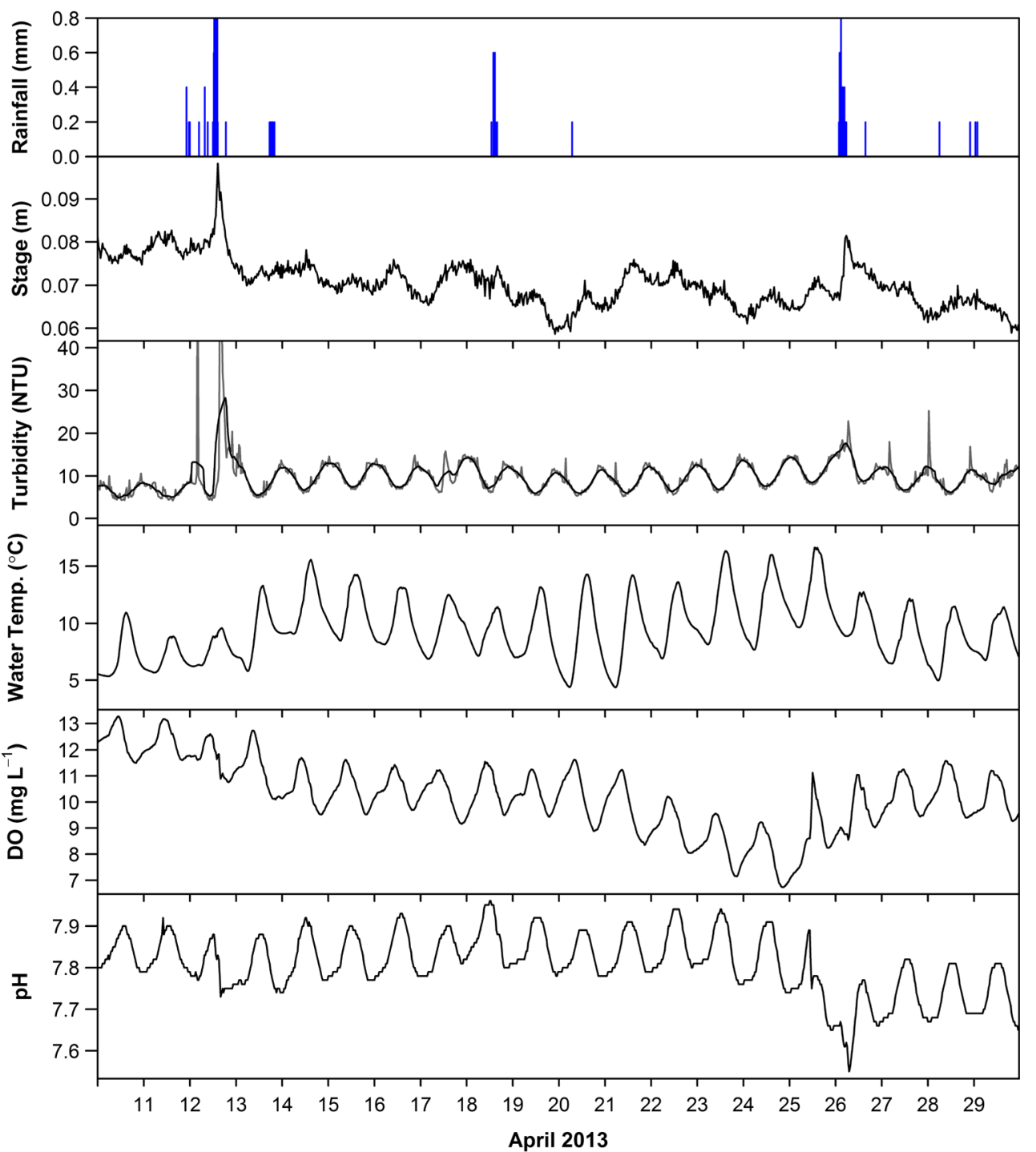


photosynthesis by submergent macrophytes and algae during the day decreasing water acidity and $\mathrm{CO}_{2}$ release at night during respiration increasing acidity (Nimick et al. 2005). Whilst correlation between $\mathrm{pH}$ and turbidity is relatively strong $(r=0.45)$, it is difficult to understand why a regular $\sim 0.1$ decrease in $\mathrm{pH}$ at night would induce a $\sim 10$ NTU increase in turbidity. This is because the more acidic conditions at night should favour dissolution, not precipitation, of carbonate material in the stream and would therefore reduce the suspended particulate fraction. Additionally, the pronounced $\sim 0.2$ decline in $\mathrm{pH}$ on the 26th April in response to a small rainfall event was not matched by a similarly pronounced shift in turbidity values, indicating low turbidity sensitivity to fluctuating $\mathrm{pH}$.

\subsection{Significance and further research}

Whilst the evidence presented here does not conclusively prove that the diel turbidity cycles witnessed in the River Blackwater were driven by bioturbation, the seasonality and timing of elevated turbidity, visual observations of crayfish activity and an absence of robust mechanistic connections with other water quality parameters means this represents a plausible causal mechanism. These findings therefore support a growing body of research highlighting the detrimental impact of non-native signal crayfish on fluvial geochemistry, fluvial geomorphology and native aquatic biota (Crawford et al. 2006; Johnson et al. 2010; Harvey et al. 2011). Their large size (typically $10-15 \mathrm{~cm}$ in length), aggressive nature, high population densities (up to 20 per square metre) and ability to rapidly colonise new environments have seen signal crayfish populations spread rapidly across Europe putting an increasing number of freshwater environments at risk (Holdich et al. 2014; Kouba et al. 2014). Further research is required in a wider range of fluvial environments at a variety of spatial and temporal scales to fully understand the importance, extent and underlying processes behind the nocturnal fine sediment mobilisation phenomena reported here.

\section{Conclusions}

Using high-resolution bankside water quality monitoring, this research presents clear evidence of pronounced diel turbidity cycles under spring baseflow conditions in a lowland headwater river. Increases in median midnight SPM concentrations of up to $76 \%$ compared to midday values, coupled with increased night-time (18:00-05:30) SPM loads of up to $30 \%$ compared with daytime $(06: 00-17: 30)$ SPM transport, are hypothesised to be caused by the nocturnal feeding and burrowing habitats of aquatic fauna, principally signal crayfish. Correlation of turbidity with other abiotic water quality parameters which similarly exhibit diel cycles (stage, temperature, dissolved oxygen and $\mathrm{pH}$ ) yielded no robust mechanistic connections which could explain the observed trends. The results presented here add to a growing body of evidence that nocturnal bioturbation may be responsible for significantly impacting upon SPM concentrations under baseflow conditions in headwater streams.

Acknowledgments RJC acknowledges financial support from a NERC BGS CASE studentship (NE/J500069/1). The authors would like to thank Jenny Stevenson, Simon Ellis and Zanist Hama-Aziz for fieldwork support and Gilla Suennenberg for providing the GIS data. We are grateful to Salle Farms Co. for their cooperation in granting land access. We thank three anonymous reviewers for their constructive comments which helped improve an earlier version of this manuscript. Further details of this study can be found in the Electronic Supplementary Material.

Open Access This article is distributed under the terms of the Creative Commons Attribution 4.0 International License (http:// creativecommons.org/licenses/by/4.0/), which permits unrestricted use, distribution, and reproduction in any medium, provided you give appropriate credit to the original author(s) and the source, provide a link to the Creative Commons license, and indicate if changes were made.

\section{References}

Beusen AHW, Dekkers ALM, Bouwman AF, Ludwig W, Harrison J (2005) Estimation of global river transport of sediments and associated particulate C, N, and P. Glob Biogeochem Cycles 19:GB4S05

Bilotta GS, Brazier RE (2008) Understanding the influence of suspended solids on water quality and aquatic biota. Water Res 42:2849-2861

Bubb DH, Lucas MC, Thorn TJ (2002) Winter movements and activity of signal crayfish Pacifastacus leniusculus in an upland river, determined by radio telemetry. Hydrobiologia 483:111-119

Cooper RJ, Rawlins BG, Lézé B, Krueger T, Hiscock K (2014) Combining two filter paper-based analytical methods to monitor temporal variations in the geochemical properties of fluvial suspended particulate matter. Hydrol Process 28:4042-4056

Cooper RJ, Krueger T, Hiscock KM, Rawlins BG (2015) High-temporal resolution fluvial sediment source fingerprinting with uncertainty: a Bayesian approach. Earth Surf Process Landf 40:78-92

Crawford L, Yeomans WE, Adams CE (2006) The impact of introduced signal crayfish Pacifastacus leniusculus on stream invertebrate communities. Aquat Conserv 16:611-621

Evans DJ, Johnes PJ, Lawrence DS (2004) Physico-chemical controls on phosphorus cycling in two lowland streams. Part 2-the sediment phase. Sci Total Environ 329:165-182

Gillain S (2005) Diel turbidity fluctuations in streams in Gwinnett County, Georgia. Proceedings of the 2005 Georgia Water Resources Conference, April 25-27 2005, University of Georgia, Georgia, USA

Guan RZ (1994) Burrowing behaviour of signal crayfish, Pacifastacus leniusculus (Dana), in the River Great Ouse, England. Freshw Forum 4:155-168

Halliday SJ, Skeffington RA, Bowes MJ, Gozzard E, Newman JR, Loewenthal M, Palmer-Felgate EJ, Jarvie HP, Wade AJ (2014) The water quality of the River Enborne, UK: observations form high-frequency monitoring in a rural, lowland river system. Water 6:150-180 
Harrington ST, Harrington JR (2013) An assessment of the suspended sediment rating curve approach for load estimation on the Rivers Bandon and Owenabue, Ireland. Geomorphology 185:27-38

Harvey GL, Moorhouse TP, Clifford NJ, Henshaw AJ, Johnson MF, Macdonald DW, Reid I, Rice SP (2011) Evaluating the role of invasive aquatic species as drivers of fine sediment-related river management problems: the case of the signal crayfish (Pacifastacus leniusculus). Prog Phys Geogr 35:517-533

Harvey GL, Henshaw AJ, Moorhouse TP, Clifford NJ, Holah H, Grey J, Macdonald DW (2014) Invasive crayfish as drivers of fine sediment dynamics in rivers: field and laboratory evidence. Earth Surf Process Landf

Hilton J, O'Hare M, Bowes MJ, Jones JI (2006) How green is my river? A new paradigm of eutrophication in rivers. Sci Total Environ 365: 66-83

Hiscock KM, Dennis PF, Saynor PR, Thomas MO (1996) Hydrochemical and stable isotope evidence for the extent and nature of the effective Chalk aquifer of north Norfolk, UK. J Hydrol 180:79-107

Holdich DM, James J, Jackson C, Peay S (2014) The North American signal crayfish, with particular reference to its success as an invasive species in Great Britain. Ethol Ecol Evol 26:232-262

House WA (2003) Geochemical cycling of phosphorus in rivers. Appl Geochem 18:739-748

Johnson MF, Rice SP, Reid I (2010) Topographic disturbances of subaqueous gravel substrates by signal crayfish (Pacifastacus leniusculus). Geomorphology 123:269-278

Johnson MF, Rice SP, Reid I (2014) The activity of signal crayfish (Pacifastacus leniusculus) in relation to thermal and hydraulic dynamics of an alluvial stream, UK. Hydrobiologia 724:41-54

Kouba A, Petrusek A, Kozák P (2014) Continental-wide distribution of crayfish species in Europe: update and maps. Knowl Manag Aquat Ecosyst 413:1-31

Lewis MA (2011) Borehole drilling and sampling in the Wensum Demonstration Test Catchment. British Geological Survey Commissioned Report, CR/11/162. 38pp, National Environment Research Council, Keyworth, Nottingham, UK

Loperfido JV, Just CL, Papanicolaou AN, Schnoor JL (2010) In situ sensing to understand diel turbidity cycles, suspended solids, and nutrient transport in Clear Creek, Iowa. Water Resour Res 46: W06525
Meteorological Office (2013) UK climate averages: Marham 1981-2010. Meteorological Office, Exeter, UK. Online: http://www.metoffice. gov.uk/public/weather/climate/\#?tab=climateTables

Meybeck M, Idlafkih Z, Fauchon N, Andreassian V (1999) Spatial and temporal variability of total suspended solids in the Seine basin. Hydrobiologia 410:295-306

Navratil O, Esteves M, Legout C, Gratiot N, Nemery J, Willmore S, Grangeon T (2011) Global uncertainty analysis of suspended sediment monitoring using turbidimeter in a small mountainous river catchment. J Hydrol 398:246-259

Navratil O, Evrard O, Esteves M, Legout C, Ayrault S, Némery J, MateMarin A, Ahmadi M, Lefèvre I, Poirel A, Bonté P (2012) Temporal variability of suspended sediment sources in an alpine catchment combining river/rainfall monitoring and sediment fingerprinting. Earth Surf Process Landf 37:828-846

Nimick DA, Cleasby TE, McCleskey RB (2005) Seasonality of diel cycles of dissolved trace-metal concentrations in a Rocky Mountain stream. Environ Geol 47:603-614

Outram FN, Lloyd CEM, Jonczyk J, Benskin CMH, Grant F, Perks MT, Deasy C, Burke SP, Collins AL, Freer J, Haygarth PM, Hiscock KM, Johnes PJ, Lovett AL (2014) High-frequency monitoring of nitrogen and phosphorus response in three rural catchments to the end of the 2011-2012 drought in England. Hydrol Earth Syst Sci 18: $3429-3448$

Quinton JN, Govers G, Oost KV, Bardgett RD (2010) The impact of agricultural soil erosion on biogeochemical cycling. Nat Geosci 3: 311-314

Rice S, Johnson M, Extence C, Reeds J, Longstaff H (2014) Diel patterns of suspended sediment flux and the zoogeomorphic agency of invasive crayfish. Cuad Investig Geogr 40:7-26

Savitzky A, Golay MJ (1964) Smoothing and differentiation of data by simplified least square procedures. Anal Chem 36:1627-1639

Sherriff SC, Rowan JS, Melland AR, Jordan P, Fenton O, hUallacháin DÓ (2015) Investigating suspended sediment dynamics in contrasting agricultural catchments using ex situ turbidity-based suspended sediment monitoring. Hydrol Earth Syst Sci 19:3349-3363

Thompson J, Cassidy R, Doogy DC, Flynn R (2014) Assessing suspended sediment dynamics in relation to ecological thresholds and sampling strategies in two Irish headwater catchments. Sci Total Environ 468-469:345-357 